Dhaka Univ. J. Sci. 64(2): 127-133, 2016 (July)

\title{
Metal Complexes of Mixed Nucleobases. Part I: Synthesis and Characterization of Copper(II), Zinc(II), Cadmium(II) and Mercury(II) Complexes of Adenine and Uracil
}

\author{
Humaira Yeasmin, M. S. Rahman, A. A. Shaikh and Pradip K. Bakshi* \\ Department of Chemistry, Dhaka University, Dhaka 1000, Bangladesh
}

(Received: 28 October 2015; Accepted: 7 April 2016)

\begin{abstract}
The complexes of $\mathrm{Cu}(\mathrm{II}), \mathrm{Zn}$ (II), Cd(II) and $\mathrm{Hg}$ (II) with adenine (AdeH) and uracil (UraH) have been synthesized and characterized by a combination of metal contents estimation, IR, UV-vis spectral data, thermogravimetric analysis (QSTG, TG and DSC) and magnetic susceptibility measurement. All the complexes are micro-crystalline, slightly soluble in water and decompose at high temperature. Both adenine and uracil deprotonated under experimental condition and then ligated to the metal ions as bidentate ligands through $\mathrm{N}(3)$ and $\mathrm{N}(9)$ of adeninato (Ade), and through $\mathrm{N}(3)$ and $\mathrm{C}(2)=\mathrm{O}$ of uracilato (Ura) anions. On the basis of the metal contents, the complexes are formulated as $\left[\mathrm{M}\left(\mathrm{C}_{5} \mathrm{H}_{4} \mathrm{~N}_{5} \mathrm{O}\right)\left(\mathrm{C}_{5} \mathrm{H}_{4} \mathrm{~N}_{5}\right)\left(\mathrm{H}_{2} \mathrm{O}\right)_{2}\right][\mathrm{M}=\mathrm{Cu}(\mathrm{II}), \mathrm{Zn}(\mathrm{II})$ and $\mathrm{Hg}(\mathrm{II})]$ and $\left[\mathrm{Cd}\left(\mathrm{C}_{5} \mathrm{H}_{4} \mathrm{~N}_{5}\right)\left(\mathrm{C}_{4} \mathrm{H}_{3} \mathrm{~N}_{2} \mathrm{O}_{2}\right)\left(\mathrm{H}_{2} \mathrm{O}\right)_{2}\right]$.2 $\mathrm{H}_{2} \mathrm{O}$. The redox properties of copper and cadmium complexes were examined in aqueous solution by cyclic voltammetry. The voltammograms show quasi-reversible behavior for both the complexes. The X-ray powder diffraction study of the copper complex indicates that it is poorly crystalline in nature.
\end{abstract}

Keywords: Nucleobase, Adenine, Uracil, Infrared spectrum, Thermogram, Magnetic susceptibility.

\section{Introduction}

Nucleobases are the basic constituents of deoxyribonucleic acid (DNA) and ribonucleic acid (RNA). The primary nucleobases are cytosine, guanine, adenine (DNA and RNA), thymine (DNA) and uracil (RNA). They are usually simply called bases in genetics. Adenine belongs to the double-ringed class of molecules called purines and uracil is pyrimidine type $\mathrm{e}^{1-5}$. The structural formula and the numbering scheme of adenine and uracil are given in scheme I.<smiles>Nc1ncnc2[nH]cnc12</smiles>

Adenine (AdeH)

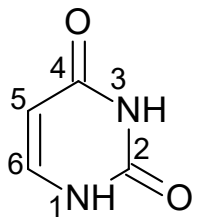

Uracil (UraH)
Scheme I. Structural representation of adenine (left) and uracil (right).

As an important part of DNA and RNA, adenine and uracil, especially their isolation, synthesis, properties and structures have been studied extensively ${ }^{6-9}$. Attention has been given in the past to their coordinating behavior with the metal ions alone as well as with other ligands ${ }^{10-12}$

The adenine complexes of several metal ions, such as Fe(II), $\mathrm{Co}(\mathrm{II}), \mathrm{Ni}(\mathrm{II}), \mathrm{Cu}(\mathrm{II}), \mathrm{Zn}(\mathrm{II}), \mathrm{Cd}(\mathrm{II}), \mathrm{Pd}(\mathrm{II})$ and $\mathrm{Pt}(\mathrm{II})$ have been reported earlier ${ }^{13-18}$. Literature review reveals that adenine is metalated through $\mathrm{N}(3), \mathrm{N}(9)$ and $\mathrm{N}(7)$ in spite of the fact that it has other sites available for coordination. The adenine-metal complexes can have tetrahedral and octahedral geometries ${ }^{19-23}$. All are of high spin in nature. Adenine behaves as a monodentate ligand in neutral but as a bidentate ligand in anionic form. On the other hand, the most common binding sites for uracil are $\mathrm{C}(2)=\mathrm{O}$ and $\mathrm{N}(3)$, though there are other donor sites ${ }^{24-26}$. The isolated divalent

\footnotetext{
* Author for correspondence. e-mail: pkb4321@yahoo.ca
}

metal complexes of uracil are with $\mathrm{Mn}(\mathrm{II}), \mathrm{Fe}(\mathrm{II}), \mathrm{Co}(\mathrm{II})$, $\mathrm{Ni}(\mathrm{II}), \mathrm{Cu}(\mathrm{II}), \mathrm{Zn}(\mathrm{II}), \mathrm{Cd}(\mathrm{II})$ and $\mathrm{Pd}(\mathrm{II})$.

It is needless to say that a systematic and extensive study of interaction of metal ions with the nucleobases is extremely important from both chemical and biochemical point of view. The existing literatures so far available in this field deals mainly with metal-adenine, and metal-uracil complexes but no report is found about the adenine-uracilmetal interaction. Under these circumstances, the first attempt of our study that is described in this report comprises synthesis, properties and structural characterization of mixed nucleobase compounds of some metal ions, $\mathrm{Cu}(\mathrm{II}), \mathrm{Zn}(\mathrm{II}), \mathrm{Cd}(\mathrm{II})$ and $\mathrm{Hg}(\mathrm{II})$ with adenine and uracil.

\section{Experimental}

Chemicals

Adenine was procured from Loba Cheme Pvt. Ltd., India, and Uracil from $\mathrm{BDH}$ chemicals Ltd., England. $\mathrm{CuCl}_{2} \cdot 2 \mathrm{H}_{2} \mathrm{O}, \mathrm{Zn}(\mathrm{OAc})_{2} \cdot 2 \mathrm{H}_{2} \mathrm{O}, \mathrm{CdCl}_{2} \cdot \mathrm{H}_{2} \mathrm{O}, \mathrm{Hg}(\mathrm{OAc})_{2} \cdot 2 \mathrm{H}_{2} \mathrm{O}$, and all other chemicals used in all synthetic and analytical work were analar grade, either Aldrich (USA), E. Merck (Germany) or E. Merck (India). All chemicals were used as received.

\section{Methods and Equipments}

The melting points of the prepared compounds were recorded on a SMP11 electrothermal melting point apparatus, Shimadzu, Japan. The metal contents of the complexes were determined complexometrically using EDTA as the titrating agent. Infrared spectra (IR) were recorded on an infrared spectrometer of model IR-470 (Shimadzu, Japan) in the range of $400-4000 \mathrm{~cm}^{-1}$ using $\mathrm{KBr}$ pellets. The UV-visible spectra of the complexes were obtained using UV-visible spectrometer, Model UV- 160A (Shimadzu, Japan), using the wavelength range of $200-600$ $\mathrm{nm}$ and water as the reference solvent. Magnetic susceptibility of the complexes was determined by the SHERWOOD SCIENTIFIC Magnetic Susceptibility Balance (M.S.B.) of model Magway MSB Mk1, Cambridge, England. The quasi-static thermal analysis (QSTG) was carried out in a 
CARBOLITE calibrated muffle furnace of the type CWF11/5. The thermogravimetric analysis was carried out with TGA-50 thermogravimetric analyzer (Shimadzu, Japan), while the differential scanning calorimetric analysis of the complexes was carried out with DSC-60 analyzer (Shimadzu, Japan). Cyclic voltammograms were recorded by electrochemical workstation (Model CHI 620D), $\mathrm{CH}$ Instruments, USA. Powder X-ray diffraction photograph of the complex was recorded in a PHILIPS PW-1729 X-ray generator equipped with XDC-700 Gunier Hägg camera, using nickel filtered $\mathrm{CuK} \alpha$ radiation $(\lambda=1.540981 \AA)$.
Synthesis

Double nucleobase containing metal complexes (adeninatouracilato- $\mathrm{M}^{2+}$ ) of $\mathrm{Cu}^{2+}, \mathrm{Zn}^{2+}, \mathrm{Cd}^{2+}$ and $\mathrm{Hg}^{2+}$ were synthesized in aqueous medium at room-temperature. Aqueous solutions of metal salts, adenine and uracil in 1:1:1 molar ratio were prepared by dissolving the requisite amounts of them in minimum volume of distilled water separately, mixed together and kept the resulting solution at ambient condition for crystallization. The product formed were isolated by filtration, washed with water, and dried in a desiccator over blue silica gel. A summarized synthetic procedure is given in Table 1 .

Table 1. Nominal Composition of reactions used for the preparation of complexes.

\begin{tabular}{llllll}
\hline Metal salts & Metal salts $/ \mathrm{g}$ & Adenine $/ \mathrm{g}$ & Uracil /g & $\mathrm{pH}$ & Complexes \\
\hline $\mathrm{CuCl}_{2} \cdot 2 \mathrm{H}_{2} \mathrm{O}$ & 0.1763 & 0.1344 & 0.1120 & 6 & {$\left[\mathrm{Cu}\left(\mathrm{C}_{5} \mathrm{H}_{4} \mathrm{~N}_{5}\right)\left(\mathrm{C}_{4} \mathrm{H}_{3} \mathrm{~N}_{2} \mathrm{O}_{2}\right)\left(\mathrm{H}_{2} \mathrm{O}\right)_{2}\right]$} \\
$\mathrm{Zn}\left(\mathrm{CH}_{3} \mathrm{COO}\right)_{2} .2 \mathrm{H}_{2} \mathrm{O}$ & 0.4402 & 0.2731 & 0.2247 & 6 & {$\left[\mathrm{Zn}\left(\mathrm{C}_{5} \mathrm{H}_{4} \mathrm{~N}_{5}\right)\left(\mathrm{C}_{4} \mathrm{H}_{3} \mathrm{~N}_{2} \mathrm{O}_{2}\right)\left(\mathrm{H}_{2} \mathrm{O}\right)_{2}\right]$} \\
$\mathrm{CdCl}_{2} \cdot \mathrm{H}_{2} \mathrm{O}$ & 0.2143 & 0.1353 & 0.1127 & 5 & {$\left[\mathrm{Cd}\left(\mathrm{C}_{5} \mathrm{H}_{4} \mathrm{~N}_{5}\right)\left(\mathrm{C}_{4} \mathrm{H}_{3} \mathrm{~N}_{2} \mathrm{O}_{2}\right)\left(\mathrm{H}_{2} \mathrm{O}\right)_{2}\right] .2 \mathrm{H}_{2} \mathrm{O}$} \\
$\mathrm{Hg}\left(\mathrm{CH}_{3} \mathrm{COO}\right)_{2} \cdot 2 \mathrm{H}_{2} \mathrm{O}$ & 0.3207 & 0.1364 & 0.1199 & 4 & {$\left[\mathrm{Hg}\left(\mathrm{C}_{5} \mathrm{H}_{4} \mathrm{~N}_{5}\right)\left(\mathrm{C}_{4} \mathrm{H}_{3} \mathrm{~N}_{2} \mathrm{O}_{2}\right)\left(\mathrm{H}_{2} \mathrm{O}\right)_{2}\right]$} \\
\hline
\end{tabular}

\section{Results and Discussion}

The empirical formulae of the complexes have been established on the basis of their metal contents. Their physical properties viz. yield, color, melting points have been studied, and listed in Table 2 .

Table 2. Metal contents and physical properties of the complexes.

\begin{tabular}{lcccc}
\hline Complexes & Metal $/ \%$ & Yield* $/ \%$ & Color and state & Melting point $/ \mathrm{K}$ \\
\hline$\left[\mathrm{Cu}(\right.$ Ade $\left.)(\mathrm{Ura})\left(\mathrm{H}_{2} \mathrm{O}\right)_{2}\right]$ & $17.19(18.38)$ & 49.31 & Deep green, crystalline & $>523$ \\
{$\left[\mathrm{Zn}(\right.$ Ade $\left.)(\mathrm{Ura})\left(\mathrm{H}_{2} \mathrm{O}\right)_{2}\right]$} & $24.85(18.81)$ & 59.72 & White, powdery & $>523$ \\
{$\left[\mathrm{Cd}(\right.$ Ade $\left.)(\mathrm{Ura})\left(\mathrm{H}_{2} \mathrm{O}\right)_{2}\right] \cdot 2 \mathrm{H}_{2} \mathrm{O}$} & $25.12(26.10)$ & 32.59 & White, powdery & $>523$ \\
{$\left[\mathrm{Hg}(\right.$ Ade $\left.)(\mathrm{Ura})\left(\mathrm{H}_{2} \mathrm{O}\right)_{2}\right]$} & $39.96(41.55)$ & 69.08 & White, powdery & $>523$ \\
\hline
\end{tabular}

Ade $=$ Anionic adenine and Ura $=$ Anionic uracil. The calculated metal contents are in parentheses. *The percentage of yield was calculated on the basis of metal contents.

IR Spectral Analysis: Tentative assignments of some important IR bands of ligands and the studied compounds were done on the basis of standard references. They are listed as shown in Table 3. The strong and broad bands in the region $3400-2400 \mathrm{~cm}^{-1}$ indicate the presence of the hydrogen bonded water molecule and/or N-H merged with aromatic $\mathrm{C}-\mathrm{H}$ stretching vibrations.

Table 3. Tentative assignments ${ }^{27}$ of IR bands of adenine, uracil and adeninato-uracilato-metal complexes.

\begin{tabular}{|c|c|c|c|c|c|c|c|}
\hline Compounds & $\begin{array}{l}v(\mathrm{O}-\mathrm{H}) \text { and /or } \\
v(\mathrm{~N}-\mathrm{H}) / \mathrm{cm}^{-1}\end{array}$ & $\begin{array}{l}v(\mathrm{C}=\mathrm{O}) \\
/ \mathrm{cm}^{-1}\end{array}$ & $\begin{array}{l}v(\mathrm{C}=\mathrm{N}) \\
/ \mathrm{cm}^{-1}\end{array}$ & $\begin{array}{l}v\left(\mathrm{C}-\mathrm{NH}_{2}\right) \\
/ \mathrm{cm}^{-1}\end{array}$ & $\begin{array}{l}v(\mathrm{C}-\mathrm{N}) \\
/ \mathrm{cm}^{-1}\end{array}$ & $\begin{array}{l}U(\mathrm{M}-\mathrm{N}) \\
/ \mathrm{cm}^{-1}\end{array}$ & $\begin{array}{l}\mathrm{u}(\mathrm{M}-\mathrm{O}) \\
/ \mathrm{cm}^{-1}\end{array}$ \\
\hline Adenine (AdeH) & $3400-3000$ & - & 1672 & 1250 & 1123 & - & - \\
\hline Uracil (UraH) & $3300-2800$ & 1716 & - & - & 1236 & - & - \\
\hline$\left[\mathrm{Cu}(\mathrm{Ade})(\mathrm{Ura})\left(\mathrm{H}_{2} \mathrm{O}\right)_{2}\right]$ & $3400-2800$ & 1650 & 1597 & 1282 & 1203 & 572 & 559 \\
\hline$\left[\mathrm{Zn}(\mathrm{Ade})(\mathrm{Ura})\left(\mathrm{H}_{2} \mathrm{O}\right)_{2}\right]$ & $3300-2900$ & 1650 & 1575 & 1270 & 1220 & 675 & 565 \\
\hline$\left[\mathrm{Cd}(\mathrm{Ade})(\mathrm{Ura})\left(\mathrm{H}_{2} \mathrm{O}\right)_{2}\right] \cdot 2 \mathrm{H}_{2} \mathrm{O}$ & $3300-2900$ & 1702 & 1612 & 1301 & 1232 & 629 & 548 \\
\hline$\left[\mathrm{Hg}(\mathrm{Ade})(\mathrm{Ura})\left(\mathrm{H}_{2} \mathrm{O}\right)_{2}\right]$ & $3300-3000$ & 1691 & 1606 & 1290 & 1182 & 680 & 575 \\
\hline
\end{tabular}


All compounds show two peaks at $1650-1716 \mathrm{~cm}^{-1}$ and at $1550-1675 \mathrm{~cm}^{-1}$ indicating the presence of both $>\mathrm{C}=\mathrm{O}$ and $>\mathrm{C}=\mathrm{N}$ - groups in them. This observation also supports that each complex contains two nucleobases involved in ligation with metal cations. In adenine the $v(\mathrm{C}=\mathrm{N})$ band is observed at $1672 \mathrm{~cm}^{-1}$, while such band in the prepared compounds is observed in the lower wavenumber region, indicating the formation of coordination bonds of adeninato anion with metal cation, through the ring nitrogens $\mathrm{N}(3)$ and $\mathrm{N}(9)$. In case of adeninato-uracilato-metal ion [metal ion $=\mathrm{Cu}$ (II), $\mathrm{Zn}$ (II), $\mathrm{Cd}(\mathrm{II})$ and $\mathrm{Hg}(\mathrm{II})]$ complexes, the position of $\mathrm{v}(>\mathrm{C}(2)=\mathrm{O})$ band shifted significantly, suggesting that the $>\mathrm{C}=\mathrm{O}$ group of uracil takes part in bonding through exocyclic $\mathrm{O}(2)$. The large shifting of $v(\mathrm{C}=\mathrm{N})$ vibration band suggests that the bonding takes place between metal ions and uracil, occurs through ring nitrogen $\mathrm{N}(3)$ and exocyclic oxygen $\mathrm{O}(2)$ of uracil. In fact, adenine and uracil loss their respective proton from $\mathrm{N}(9)-\mathrm{H}$ and $\mathrm{N}(3)-\mathrm{H}$ in the reaction medium, forming respective anions, which then coordinated to the metal ions through $\mathrm{N}(3)$ and $\mathrm{N}(9)$ of adeninato, and $\mathrm{N}(3)$ and $\mathrm{C}(2)=\mathrm{O}$ of uracilato anions. Two water molecules complete the octahedral coordination environment of each metal cation. The $v(\mathrm{M}-\mathrm{N})$ and $v(\mathrm{M}-\mathrm{O})$ vibrations appears in the region of $675-550 \mathrm{~cm}^{-1}$. A schematic view of the ligation of metal ions with adeninato and uracilato ligands is shown in scheme II.<smiles>Nc1ncnc2[nH]cnc12</smiles><smiles>O=c1cc[nH]c(=O)[nH]1</smiles>

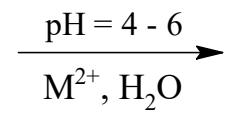

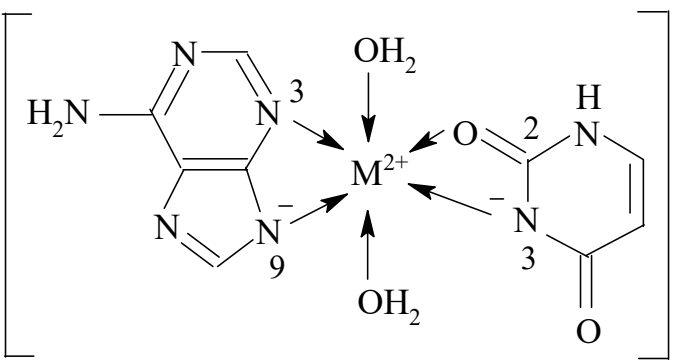

Scheme II. Reaction scheme of metal-ligands interaction.

UV-Vis Spectral Analysis: All four complexes are slightly soluble in water. Their electronic spectra were recorded in aqueous solution. The spectral data of the compounds are tabulated in Table 4. All compounds show a strong absorption band in the range of $226-230 \mathrm{~nm}$ possibly due to $\sigma \rightarrow \sigma^{*}$ transition.

Table 4. Electronic spectral data of the studied compounds.

\begin{tabular}{ll}
\hline Complexes & $\lambda / \mathrm{nm}$ \\
\hline$\left[\mathrm{Cu}(\right.$ Ade $\left.)(\mathrm{Ura})\left(\mathrm{H}_{2} \mathrm{O}\right)_{2}\right]$ & 230,262 \\
{$\left[\mathrm{Zn}(\right.$ Ade $\left.)(\mathrm{Ura})\left(\mathrm{H}_{2} \mathrm{O}\right)_{2}\right]$} & 228,260 \\
{$\left[\mathrm{Cd}(\right.$ Ade $\left.)(\mathrm{Ura})\left(\mathrm{H}_{2} \mathrm{O}\right)_{2}\right] \cdot 2 \mathrm{H}_{2} \mathrm{O}$} & 226,260 \\
{$\left[\mathrm{Hg}(\right.$ Ade $\left.)(\mathrm{Ura})\left(\mathrm{H}_{2} \mathrm{O}\right)_{2}\right]$} & 232,342 \\
\hline
\end{tabular}

They also show band at around $260 \mathrm{~nm}$ possibly due to $\pi \rightarrow \pi^{*}$ and $n \rightarrow \pi^{*}$ electronic transitions in the ethylenic bonds of the heteroaromatic ring within the ligands.

Though the $\mathrm{Cu}^{2+}$ containing compound is deep green and sparingly soluble in water, it does not show any band in the visible region of the spectrum.
Magnetic Susceptibility: Magnetic measurements of the compounds were carried out, and the results are gathered in Table 5. Compound $\left[\mathrm{Cu}(\mathrm{Ade})(\mathrm{Ura})\left(\mathrm{H}_{2} \mathrm{O}\right)_{2}\right]$ is paramagnetic with magnetic moment of $1.67 \mathrm{BM}$, representing the presence of one unpaired electron in its $3 d$ orbitals $^{28} . \mathrm{Cu}$ (II) is a $d^{9}$ ion, and in octahedral arrangement of ligands it has one unpaired electron in $e_{g}$ level. The spin only value $\left(\mu_{\mathrm{eff}}\right)$ for an ion possessing one unpaired electron is $1.73 \mathrm{BM}$.

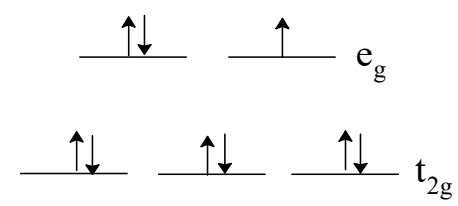

However, the magnetic susceptibility values of zinc(II), cadmium(II) and mercury(II) compounds are either negative or zero suggesting their diamagnetic character. The metals are in divalent state and have $d^{10}$ electronic configuration in which all the $d$-electrons in $t_{2 g}$ and $e_{g}$ levels are paired.

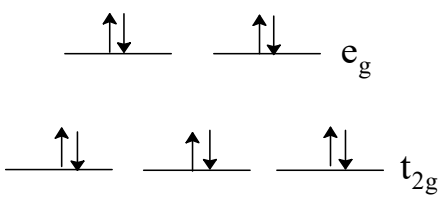


Table 5. Magnetic measurement data of the prepared compounds.

\begin{tabular}{|c|c|c|c|c|c|c|c|c|}
\hline Compounds & $\mathrm{C}_{\mathrm{Ba} 1}$ & $1 / \mathrm{cm}$ & $\mathrm{m} / \mathrm{g}$ & $\mathrm{R}$ & $\mathrm{R}_{\mathrm{o}}$ & $\chi_{\mathrm{g}} /$ C.G.S. unit & $\mathrm{T} / \mathrm{K}$ & $\mu_{\mathrm{eff}} / \mathrm{BM}$ \\
\hline$\left[\mathrm{Cu}(\mathrm{Ade})(\mathrm{Ura})\left(\mathrm{H}_{2} \mathrm{O}\right)_{2}\right]$ & 0.9954 & 2.00 & 0.1452 & 154 & -33 & $2.5639 \times 10^{-6}$ & 296 & 1.67 \\
\hline$\left[\mathrm{Zn}(\mathrm{Ade})(\mathrm{Ura})\left(\mathrm{H}_{2} \mathrm{O}\right)_{2}\right]$ & 0.9954 & 2.20 & 0.0542 & -43 & -34 & $-3.6363 \times 10^{-7}$ & 296 & 0 \\
\hline $\begin{array}{r}{\left[\mathrm{Cd}(\text { Ade })(\mathrm{Ura})\left(\mathrm{H}_{2} \mathrm{O}\right)_{2}\right]} \\
.2 \mathrm{H}_{2} \mathrm{O}\end{array}$ & 0.9945 & 2.10 & 0.1221 & -39 & -34 & $-8.5522 \times 10^{-8}$ & 296 & 0 \\
\hline$\left[\mathrm{Hg}(\mathrm{Ade})(\mathrm{Ura})\left(\mathrm{H}_{2} \mathrm{O}\right)_{2}\right]$ & 0.9963 & 2.20 & 0.1114 & -44 & -33 & $-2.1643 \times 10^{-7}$ & 296 & 0 \\
\hline
\end{tabular}

Thermal Analysis: The thermograms obtained from the thermogravimetric analysis of the adeninato-uracilato-metal compounds are plotted in Fig. 1 for their comparative study. The figure shows that copper(II) and zinc(II) compounds start losing weight at around $50^{\circ} \mathrm{C}$, whereas compounds of cadmium(II) and mercury(II) are fairly stable up to $150^{\circ} \mathrm{C}$. In each case the first step of decomposition corresponds to the loss of two molecules of water. Beyond that the process of decomposition is relatively rapid and occurs in several steps which suggest that the remaining portion of the ligands is lost in fragments. It is observed that the residue of copper(II) and zinc(II) compounds attain a constant weight at $450^{\circ} \mathrm{C}$ and $550^{\circ} \mathrm{C}$ respectively. The residues are identified as $\mathrm{CuO}$ and $\mathrm{ZnO}$ by their chemical analysis. The end products of cadmium(II) and mercury(II) compounds are volatile clearly indicated by the continuous falling off their thermograms with increasing temperature. The thermogravimetric analysis (TGA) reveals a similar trend of thermal behavior of above compounds. The DSC analysis shows that the decomposition processes are both exothermic and endothermic in nature. On the basis of thermal stability the compounds under study are arranged in the following order:

$\mathrm{Cd}($ II $)>\mathrm{Hg}($ II $)>\mathrm{Cu}($ II $)>\mathrm{Zn}($ II $)$.

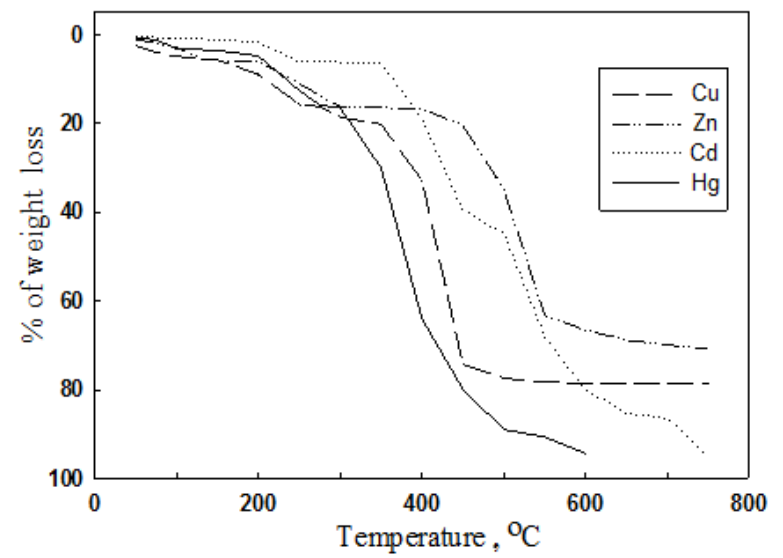

Fig. 1. QSTG plots of $\left[\mathrm{M}(\mathrm{Ade})(\mathrm{Ura})\left(\mathrm{H}_{2} \mathrm{O}\right)_{2}\right](\mathrm{M}=\mathrm{Cu}(\mathrm{II}), \mathrm{Zn}(\mathrm{II})$ and $\mathrm{Hg}(\mathrm{II})$ and $\left[\mathrm{Cd}\right.$ (Ade) $\left.(\mathrm{Ura})\left(\mathrm{H}_{2} \mathrm{O}\right)_{2}\right] \cdot 2 \mathrm{H}_{2} \mathrm{O}$.

Cyclic Voltammetric Study: The cyclic voltammetric behavior of $1.0 \mathrm{mM} \mathrm{Cu}$ (II) and $1.0 \mathrm{mM} \mathrm{Cd}$ (II) alone and in presence of adenine and uracil in $1.0 \mathrm{M} \mathrm{KCl}$ solution has also been investigated, and compared with their respective double nucleobase complexes. Cyclic voltammograms of copper(II), cadmium(II), adenine, uracil, [Cu(Ade)(Ura) $\left.\left(\mathrm{H}_{2} \mathrm{O}\right)_{2}\right]$ and $\left[\mathrm{Cd}(\mathrm{Ade})(\mathrm{Ura})\left(\mathrm{H}_{2} \mathrm{O}\right)_{2}\right] \cdot 2 \mathrm{H}_{2} \mathrm{O}$ are plotted in the Fig. 2 and Fig. 3. It is observed that the peak currents and the peak potentials of $\mathrm{Cu}$ (II) and $\mathrm{Cd}$ (II) (Fig. 2 and 3) have been shifted in presence of ligands relative to those of their free state, indicating metal-ligand interactions have been taken place in aqueous medium. $\mathrm{Cu}$ (II) species shows two step one-electron transfer redox behavior, e.g. $\mathrm{Cu}(\mathrm{II}) / \mathrm{Cu}(\mathrm{I})$ and $\mathrm{Cu}(\mathrm{I}) / \mathrm{Cu}(0))$. From the shape of the voltammograms, peak current ratio, and peak potential separation it is understood that $(\mathrm{Cu}(\mathrm{II}) / \mathrm{Cu}(\mathrm{I}))$ is reversible and $\mathrm{Cu}(\mathrm{I}) / \mathrm{Cu}(0)$ is quasi-reversible. On the other hand $\mathrm{Cd}$ (II) species gives a redox couple $\mathrm{Cd}(\mathrm{II}) / \mathrm{Cd}(0)$ which is quasi-reversible in nature.

In the case of copper complex, the redox system of $\mathrm{Cu}(\mathrm{II}) / \mathrm{Cu}(\mathrm{I})$ is irreversible while $\mathrm{Cu}(\mathrm{I}) / \mathrm{Cu}(0)$ is quasireversible (peak current ratio 3.07-3.29) and those for cadmium complex, $\mathrm{Cd}(\mathrm{II}) / \mathrm{Cd}(0)$ is quasi-reversible (peak current ratio 5.30-5.98) (Table 6). The peak potential separation increases with increasing scan rate (Fig. 4 and 5) which also indicate the redox processes are quasi-reversible. Moreover, the shifting of the peak potentials at various scan rates agrees well with the quasi-reversibility of the redox processes $^{29}$.

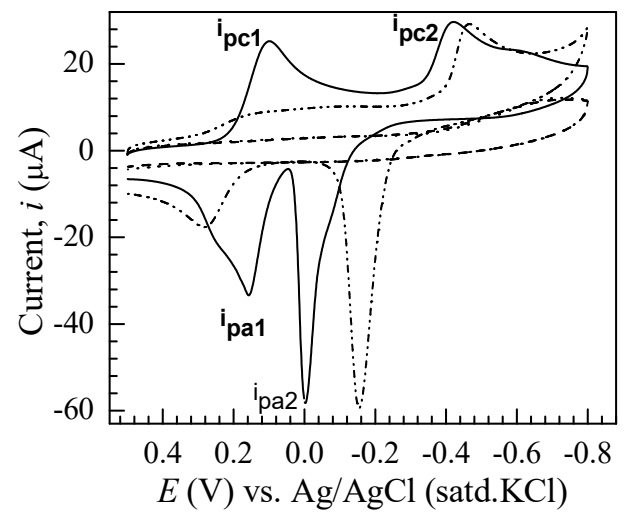

Fig. 2. Cyclic voltammograms of $1.0 \mathrm{mM} \mathrm{Cu}$ (II) (solid), adenine (dash), uracil (dot) and $\left[\mathrm{Cu}(\right.$ Ade $\left.)(\mathrm{Ura})\left(\mathrm{H}_{2} \mathrm{O}\right)_{2}\right]$ (dash dot dot) in 1.0 $\mathrm{M} \mathrm{KCl}$ solution. 


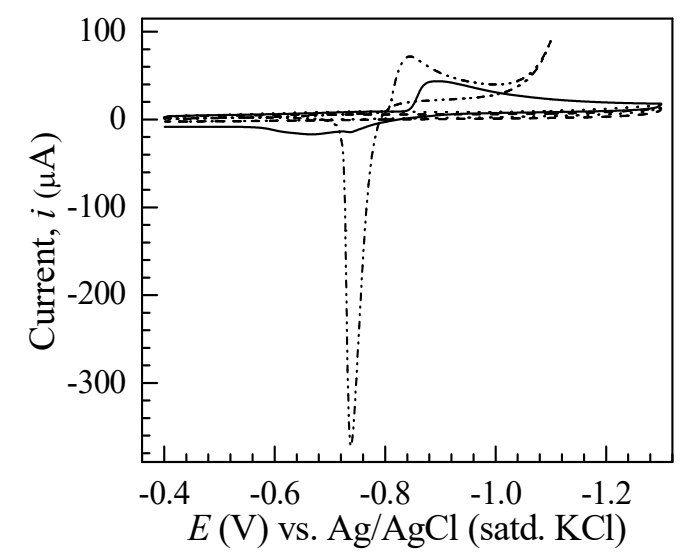

Fig. 3. Cyclic voltammograms of $1.0 \mathrm{mM} \mathrm{Cd}(\mathrm{II})$ (soild), adenine (dash), uracil (dot) and $\left[\mathrm{Cd}(\mathrm{Ade})(\mathrm{Ura})\left(\mathrm{H}_{2} \mathrm{O}\right)_{2}\right] \cdot 2 \mathrm{H}_{2} \mathrm{O}$ (dash dot dot) in $1.0 \mathrm{M} \mathrm{KCl}$ solution.

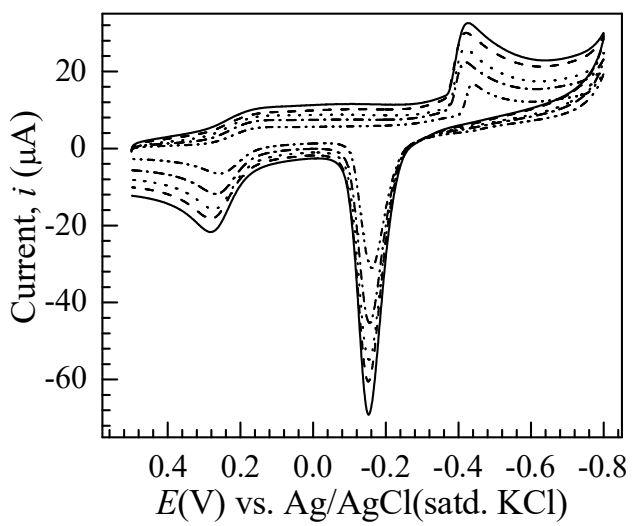

Fig. 4. Cyclic voltammograms of $1.0 \mathrm{mM}\left[\mathrm{Cu}(\right.$ Ade $\left.)(\mathrm{Ura})\left(\mathrm{H}_{2} \mathrm{O}\right)_{2}\right]$ in $1.0 \mathrm{M} \mathrm{KCl}$ solution at scan rate of 25 (dash dot dot), 50 (dash dot), 75 (dot), 100 (dash), 125 (solid) $\mathrm{mVs}^{-1}$.

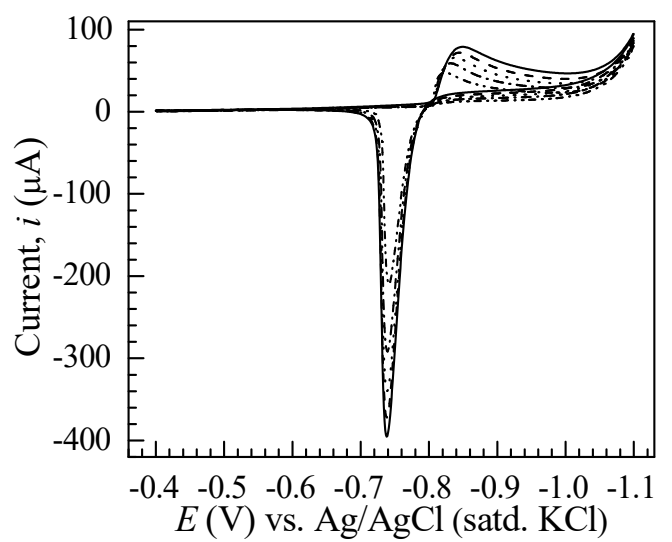

Fig. 5. Cyclic voltammograms of $1.0 \mathrm{mM}\left[\mathrm{Cd}(\mathrm{Ade})(\mathrm{Ura})\left(\mathrm{H}_{2} \mathrm{O}\right)_{2}\right]$. $2 \mathrm{H}_{2} \mathrm{O}$ in $1.0 \mathrm{M} \mathrm{KCl}$ solution at scan rate of 25 (dash dot dot), 50 (dash dot), 75 (dot), 100 (dash) and 125 (solid) $\mathrm{mVs}^{-1}$.

Powder X-ray Diffraction: The powder X-ray diffraction of all compounds were recorded but only $[\mathrm{Cu}$ (Ade)(Ura) $\left.\left(\mathrm{H}_{2} \mathrm{O}\right)_{2}\right]$ showed a few weak diffraction lines. The $d$-values of them were measured and shown in Table 7. The cause of showing a few weak and /no diffraction lines are that either they belong to higher symmetry crystal systems, or they are poorly crystalline which do not diffract well.

Table 6. Change of peak currents and peak potentials with scan rates of the studied compounds.

\begin{tabular}{|c|c|c|c|c|c|c|}
\hline $\begin{array}{l}\text { Scan rate, } v \\
/ \mathrm{mVs}^{-1}\end{array}$ & $\begin{array}{l}\text { Cathodic peak } \\
\text { current } \\
i_{p c 2} / \mu \mathrm{A}\end{array}$ & $\begin{array}{c}\text { Anodic peak } \\
\text { current, } \\
i_{p a 2} / \mu \mathrm{A} \\
(-) \\
\end{array}$ & $\begin{array}{l}\text { Cathodic peak } \\
\text { potential, } E_{p c l} \\
\qquad / \mathrm{mV} \\
(-)\end{array}$ & $\begin{array}{c}\text { Anodic peak } \\
\text { potential, } E_{p a l} \\
/ \mathrm{mV} \\
(-)\end{array}$ & $\begin{array}{l}\text { Peak current } \\
\text { ratio, } i_{p a 2} / i_{p c 2}\end{array}$ & $\begin{array}{l}\text { Peak potential } \\
\text { separation, } \Delta E_{p} \\
\text { /mV }\end{array}$ \\
\hline \multicolumn{7}{|c|}{$1.0 \mathrm{mM}\left[\mathrm{Cu}(\mathrm{Ade})(\mathrm{Ura})\left(\mathrm{H}_{2} \mathrm{O}\right)_{2}\right]$ in $1.0 \mathrm{M} \mathrm{KCl}$ solution } \\
\hline 25 & 9.937 & 32.49 & 440.1 & 161.0 & 3.2695 & 279.1 \\
\hline 50 & 14.94 & 46.55 & 418.0 & 155.0 & 3.1157 & 263.0 \\
\hline 75 & 17.24 & 56.06 & 419.0 & 153.0 & 3.2517 & 266.0 \\
\hline 100 & 19.94 & 61.23 & 421.0 & 152.0 & 3.0707 & 269.0 \\
\hline 125 & 21.17 & 69.81 & 426.0 & 153.0 & 3.2975 & 273.0 \\
\hline \multicolumn{7}{|c|}{$1.0 \mathrm{mM}\left[\mathrm{Cd}(\mathrm{Ade})(\mathrm{Ura})\left(\mathrm{H}_{2} \mathrm{O}\right)_{2}\right] .2 \mathrm{H}_{2} \mathrm{O}$ in $1.0 \mathrm{M} \mathrm{KCl}$ solution } \\
\hline 25 & 41.1 & 220.8 & 824 & 741 & 5.30 & 83 \\
\hline 50 & 53.39 & 304.9 & 832 & 739 & 5.71 & 93 \\
\hline 75 & 60.01 & 354.7 & 838 & 739 & 5.91 & 99 \\
\hline 100 & 65.02 & 388.8 & 845 & 738 & 5.98 & 107 \\
\hline 125 & 70.93 & 414.2 & 849 & 738 & 5.84 & 111 \\
\hline
\end{tabular}


Table 7. The $d$-values calculated from the powder X-ray diffraction pattern of $\left[\mathrm{Cu}(\mathrm{Ade})(\mathrm{Ura})\left(\mathrm{H}_{2} \mathrm{O}\right)\right]$.

\begin{tabular}{lccc}
\hline $\begin{array}{l}\text { Relative } \\
\text { intensity }\end{array}$ & $l / \mathrm{mm}$ & $\theta /^{\circ}$ & Calcd. $d / \AA ̊$ \\
\hline Weak & 21.50 & 6.30 & 7.02 \\
Very weak & 22.72 & 6.65 & 6.65 \\
Strong & 24.84 & 7.28 & 6.08 \\
Very weak & 28.47 & 8.34 & 5.31 \\
Very weak & 30.29 & 8.87 & 4.99 \\
\hline
\end{tabular}

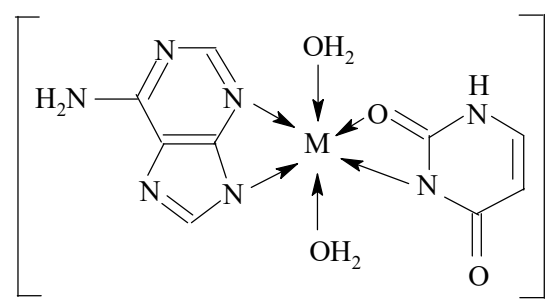

$\left[\mathrm{M}(\right.$ ade $\left.)(\mathrm{Ura})\left(\mathrm{H}_{2} \mathrm{O}\right)_{2}\right],[\mathrm{M}=\mathrm{Cu}(\mathrm{II}), \mathrm{Zn}(\mathrm{II})$ and $\mathrm{Hg}(\mathrm{II})]$

\section{Acknowledgement}

Gratefully acknowledge to University Grants Commission of Bangladesh for its financial support to the authors.

\section{References}

1. Yakovchuk, P., E. Protozanova and M. D. Frank-Kamenetskii, 2006. Base-stacking and Base-pairing Contributions into Thermal Stability of the DNA Double Helix. Nucleic Acids Res., 34(2), 564-74.

2. Goodman, L. S. and A. Gilman, 1985. The Pharmacological Basis of Therapeutics. $7^{\text {th }}$ Edition, NY: Macmillan, New York.

3. Shaprio, R., 1995. The Periodic Role of Adenine: A Critical Analysis. Orig. Life Evol. Biosph., 25, 83-98.

4. Mashiyama, S. T., C. Courtemanche, I. Elson-Schwab, J. Crott, B. L. Lee, V. N. Ong, M. Fenech and B. N. Ames, 2004. Uracil in DNA, Determined by an Improved Assay, is Increased When Deoxynucleosides are Added to Folatedeficient Cultured Human Lymphocytes. Anal. Biochem., 330(1), 58-69.

5. Holleman, A. F., N. Wiberg and E. Wiberg., 1985. Lehrbuch der Anorganischen Chemie. 91-100 Edition, Walter de Gruyter \& Co. Berlin.

6. Aoki, K. in: J.-M. Lehn (Ed.), 1996. Comprehensive Supramolecular Chemistry, 5, Pergamon Press, Oxford, Chapter 8.

7. Sigel, A. and H. Sigel, (Ed.), 1996. Metal Ions in Biological Systems, Interaction of Metal Ions with Nucleotides. Nucleic Acids and their Constituents, 32, 579-602, Marcel Dekker, New York, USA.

8. Sigel, A. and H. Sigel (Ed.), 1996. Metal Ions in Biological Systems, 33, 537- 560, Dekker, New York.

\section{Conclusion}

Reaction of copper(II), zinc(II), cadmium(II) and mercury(II) with adenine, and uracil gave ternary complexes in aqueous solution. The complexes are micro-crystalline solid, slightly soluble in water and having high decomposition point. Estimations of metal content of the studied compounds are in good agreement with the theoretically calculated values of the proposed formulae. Investigations of their physico-chemical properties indicated that both adenine and uracil behave as bidentate ligand. Adeninato ion chelated through $\mathrm{N}(3)$ and $\mathrm{N}(9)$ and uracilato ion through $\mathrm{N}(3)$ and $\mathrm{C}(2)=\mathrm{O}$. On the basis of our experimental results, the most probable structures of the studied compounds are given below:

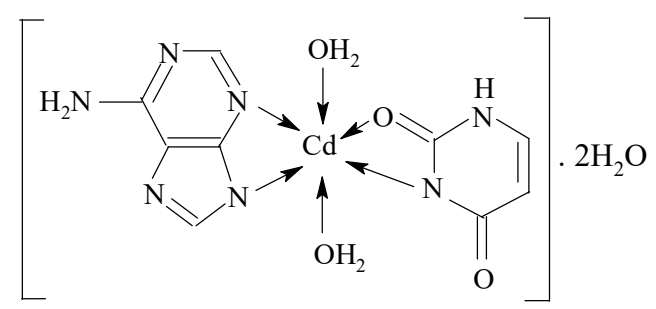

$\left[\mathrm{Cd}(\right.$ ade $\left.)(\mathrm{Ura})\left(\mathrm{H}_{2} \mathrm{O}\right)_{2}\right] \cdot 2 \mathrm{H}_{2} \mathrm{O}$

9. Hud, N.V. (Ed.), 2009. Nucleic Acid-Metal Ion Interactions, Royal Society of Chemistry Publishing, Cambridge, UK.

10. Hadjiliadis, N. and E. Sletten (Ed.), 2009. Metal ComplexDNA Interactions, John Wiley \& Sons, Chichester, UK.

11. Sigel, A., H. Sigel and P.K.O. Sigel (Ed.), 2011. Metal Ions in Life Sciences, 9, 279-317, Royal Society of Chemistry, Cambridge, UK.

12. Sigel, A., H. Sigel and P.K.O. Sigel (Ed.), 2012. Metal Ions in Life Sciences, 10, 125-167, Springer, Dordrecht/Heidelberg/ London/NY.

13. Masoud, M. S., A. A. Soayed and A. E. Ali, 2004. Complexing Properties of Nucleic Acid Constituents Adenine and Guanine Complexes. Spectrochim. Acta A., 60(8), 19071915.

14. Brandi-Blanco, M. P., D. C. Lazarte, C. G. G. Collado, J. M. G. Pérez, A. Castiñeiras and J. N. Gutiérrez, 2005. The First Metal Chelate of Unsubstituted 2,6-Pyridine-dicarboximide(pdcam): Synthesis, Molecular and Crystal Structure, and Properties of $\left[\mathrm{Cu}^{\mathrm{II}}(\mathrm{pdc})(\mathrm{pdcam})\right] \cdot 2 \mathrm{H}_{2} \mathrm{O}$ (pdc = 2,6-pyridine-dicarboxylato(2)ligand). Inorg. Chem. Commun., 8, 231-234.

15. Gavilán, M. D., A. C. García, O. C. López, M. C. Núñez, D. C. Lazarte, J. M. G. Pérez, F. R. Serrano, J. A. Marchal, A. Aránega, M. A. Gallo, A. Espinosa and J. M. Campos, 2008. Synthesis and Anticancer Activity of (R,S)-9-(2,3-Dihydro-1,4benzoxathiin-3-ylmethyl)-9H-Purines. Chem. Med. Chem., 3, 127-135.

16. Díaz-Gavilán, M., D. Choquesillo- Lazarte, J. M. GonzálezPérez, M. A. Gallo, A. Espinosa and J. M. Campos, 2007. Synthesis and Reactivity of (RS)-6-chloro-7- or 9-(1,2,3,5tetrahydro-4,1-benzoxazepin-3-yl)-7H- or 9H-purines Bearing Nitrobenzensulfonyl Group on the Nitrogen Atom. Tetrahedron, 63, 5274-5286. 
17. Blanco, M. P. B., B. D. Fernandes, J. M. G. Pérez and D. C. Lazarte, 2007. A Redetermination of (N9-adenine-[kappa]N) aqua-[glycylglycinato(2-)-[kappa]3N,N',O] copper(II), Acta Cryst., E, 63(6), 96-99.

18. L. Nahar, $4^{\text {th }}$ year B. Sc. (Hons.) Project, February, 2008.

19. Basallote, M. G., R. Vilaphana and F. W. Vilchez, 1986. Palladium and Platinum Guanine Complexes. Transit. Metal Chem., 11, 232-235.

20. Mukherjea, K. K. and I. Bhaduri, 2002. Metallo-guanines and Metallo-guanosines. Transit. Metal Chem., 27, 22-26.

21. Moriwaki, H., 2002. Complexes of Cadmium Ion with Guanine Bases Detected by Electrospray Ionization Mass Spectrometry. Journal of Mass Spectrometry., 38(3), 321-327.

22. Gaballa, A. S., H. Schmidt, C. Wagner, and D. Steinborn, 2008. Structure and Characterization of Platinum(II) and Platinum(IV) Complexes with Protonated Nucleobase Ligands. Inorg. Chim. Acta., 361(7), 2070-2080.

23. Mastropietro, T. F., D. Armentano, E. Grisolia, C. Zanchini, F. Lloret, M. Julve and G. D. Munno, 2008. Guanine Containing Copper(II) Complexes: Synthesis, X-ray Structures and Magnetic Properties. Dalton Trans., 30, 514-520.
24. Ghosh, P., T. K. Mukhopadhay and A. R. Sankar, 1984. Interaction of Divalent Metal Ions with Uracil III. Complexes of $\mathrm{Mn}(\mathrm{II}), \mathrm{Fe}(\mathrm{II}), \mathrm{Co}(\mathrm{II}), \mathrm{Ni}(\mathrm{II})$ and $\mathrm{Cu}(\mathrm{II})$ with Uracil Acting as Bidentate Ligand. Transit. Metal Chem., 9(2), 46-48.

25. Gupta, M. and M. N. Srivastava, 1985. Synthesis and Characterization of Mixed Ligand Complexes of Copper(II), Nickel(II), Cobalt(II) and Zinc(II) with Glycine and Uracil or 2-Thiouracil. Polyhedron., 4(3), 475-479.

26. Olmez, H., O. Z. Yesilel and H. Icbudak, 2000. Thermal Studies on Solid Complexes of Uracil with Some Divalent Transition Metal Ions. J. Therm. Anal. Calorim., 63(1), 105116.

27. Pavia, D. L., G. P. Lampman and G. S. Kriz, 2000. Introduction to Spectroscopy. $3^{\text {rd }}$ Edition, Washington.

28. Dutta, R. L. and A. Syamal, 1993. Elements of Magnetochemistry, Affiliated East-Wast Press Pvt. Ltd. $2^{\text {nd }}$ Edition, p. 47.

29. Quentel, F. and C. Madec, 1990.Voltammetric Study of the Copper-1,10-phenanthroline Complex. Anal. Chem. Acta., 230, 83-90. 